\title{
Penggunaan Media Film Dalam Meningkatkan Motivasi Belajar Peserta Didik Pada Mata Pelajaran Pendidikan Kewarganegaraan
}

\author{
Reza Gunawan \\ Tetep \\ Reza_gunawan@gmail.com \\ Tevs_gaya@yahoo.co.id
}

\begin{abstract}
ABSTRAK_Penelitian ini bertujuan untuk mengetahui seberapa besar pengaruh penggunaan media film dalam meningkatkan motivasi belajar peserta didik pada mata pelajaran Pendidikan Kewarganegaraan di SMA Negeri 6 Garut. Metode yang digunakan dalam penelitian ini adalah metode True Experimental. Data yang diperoleh dari penelitian ini adalah dengan Tes, wawancara, observasi, dan angket. Berdasarkan hasil penyebaran angket penelitian ini mengungkapkan bahwa: 1.Motivasi belajar peserta didik pada mata pelajaran Pendidikan Kewarganegaraan sebelum digunakan media film di kelas X SMA Negeri 6 Garut tergolong dalam kategori sangat rendah. 2.Motivasi belajar peserta didik pada mata pelajaran Pendidikan Kewarganegaraan sesudah digunakan media film di kelas X SMA Negeri 6 Garut tergolong dalam kategori sangat baik. 3.Media film memiliki peranan yang positif dan signifikan dalam meningkatkan motivasi belajar peserta didik pada mata pelajaran Pendidikan Kewarganegaraan di kelas X SMA Negeri 6 Garut berdasarkan hasil analisis data dengan menggunakan uji korelasi dan uji gain ternormalisasi hasil koefisien korelasi yaitu sebesar 32,9\% dan sisanya sebesar $67,1 \%$ dipengaruhi oleh variabel lain.
\end{abstract}

Kata kunci: Media Pembelajaran Film, Motivasi Belajar, Mata Pelajaran PKn.

\section{PENDAHULUAN}

Salah satu komponen dalam keberhasilan mutu pendidikan yaitu terletak dari sumber daya manusia yang berkualitas dalam dunia pendidikan yaitu guru atau pendidik. Di sekolah guru merupakan figur yang dijadikan teladan bagi setiap peserta didik. Sebab menurut Aqib (2009:3) "guru adalah sosok manusia yang harus digugu dan ditiru, predikat itu disandang dari pagi kala dia bangun tidur sampai malam saat masuk peraduan".

Guru juga merupakan salah satu komponen utama dalam sistem pendidikan yang bertanggungjawab melaksanakan sistem pembelajaran dengan baik karena tugas dari seorang guru terdapat dalam dua hal yaitu sebagai pengajar dan pendidik. Sebagai pengajar guru bertugas untuk menuangkan sejumlah bahan pelajaran atau pengetahuan kedalam diri atau otak peserta didik, sedangkan sebagai pendidik yaitu guru bertugas untuk membimbing dan membina peserta didik agar menjadi manusia yang berkarakter, aktif, kreatif dan mandiri. Menurut Tetep (2015:41) bahwa idealnya guru adalah orang yang berpengalaman dalam bidang profesinya, dengan keilmuan yang dimilikinya, dia dapat menjadikan anak didik menjadi orang yang cerdas

Guru dalam proses belajar mengajar baik di dalam kelas maupun di luar kelas harus mampu menjadi pengendali, pemegang sentral utama dalam pembelajaran. Sehingga sudah selayaknya seorang guru selalu berupaya menciptakan suasana belajar yang menantang, memotivasi, meningkatkan hasrat belajar dan membuat suasana belajar yang menyenangkan bagi peserta didik sehingga gairah belajar peserta didik jadi termotivasi terutama dalam pelajaran Pendidikan Kewarganegaraan. 
Pendidikan Kewarganegaraan merupakan salah satu dari sekian banyak mata pelajaran yang harus diajarkan mulai dari sekolah dasar, sekolah menengah pertama, sekolah menengah atas sampai ke perguruan tinggi di Indonesia. Sebagai mata pelajaran wajib yang di berikan di sekolah, maka Pendidikan Kewarganegaraan harus memiliki tujuan tertentu yang harus dicapai dalam proses pembelajaran. Berbagai masalah muncul ketika proses pembelajaran Pendidikan Kewarganegaraan berlangsung khususnya pada tingkat sekolah menengah atas (SMA) dengan ditunjukkannya minat, ketertarikan dan motivasi belajar peserta didik yang rendah hal ini ditunjukkan ketika penulis melaksanakan Program Pengamalan Lapangan (PPL) di Sekolah Menengah Atas khususnya di SMA Negeri 6 Garut. Masalah lain yang sering muncul dalam pembelajaran Pendidikan Kewarganegaraan Menurut Nurjanah (2013:3). Bahwa "mata pelajaran pendidikan kewarganegaraan merupakan mata pelajaran yang kurang diminati oleh siswa dan dianggap sebagai pelajaran yang sangat membosankan, selain dianggap pelajaran yang membosankan juga pelajaran yang tidak dimasukan ke dalam pelajaran yang di Ujian Nasionalkan". Berdasarkan pendapat diatas dapat memperkuat alasan peserta didik untuk tidak menyenangi pelajaran Pendidikan Kewarganegaraan dan belajar Pendidikan Kewarganegaraan itu sesuatu hal yang kurang penting. Pada realitanya di lapangan ternyata sampai saat ini, masih terdapat kesan bahwa mata pelajaran Pendidikan Kewarganegaraan adalah sebagai mata pelajaran yang kurang menarik dan rendahnya motivasi belajar peserta didik terhadap pelajaran tersebut.

Metode dan media pembelajaran yang sering digunakan pun menjadi salah satu hal yang membuat peserta didik kurang tertarik dengan mata pelajaran Pendidikan Kewarganegaraan. Karena banyak sekali guru selaku penanggung jawab dalam proses pembelajaran masih banyak yang menggunakan model serta media pembelajaran konvensional tanpa menggunakan alat bantu media apapun, dimana peserta didik hanya duduk, mencatat dan mendengarkan apa yang disampaikan oleh guru. Sehingga motivasi belajar peserta didik dalam pelajaran Pendidikan Kewarganegaraan menjadi rendah, padahal salah satu indikator keberhasilan tercapainya tujuan pembelajaran di lihat dari semangat belajar peserta didik dan motivasi peserta didik terhadap pelajaran tersebut.

Adapun keadaan lingkungan di SMA Negeri 6 Garut, ditemukan bahwa kondisi motivasi belajar peserta didik pada mata pelajaran Pendidikan Kewarganegaraan saat ini masih tergolong rendah, kondisi ini dapat dilihat dari aktivitas peserta didik ketika sedang belajar. Dimana masih banyak peserta didik yang kurang merespon bahkan masih ada peserta didik yang malah asik main handphone dengan sembunyi-sembunyi agar tidak terlihat oleh guru, ada pula peserta didik yang mengantuk dan kurang fokusnya ketika proses pembelajaran berlangsung, padahal tujuan dari proses pembelajaran Pendidikan Kewarganegaraan itu sendiri, yaitu untuk menciptakan suasana kelas yang aktif, kreatif, dinamis dan kritis dalam pembelajaran. Hal ini dimungkinkan karena tidak adanya media pembelajaran yang digunakan oleh guru, selain itu juga guru kurang variatif dalam menyampaikan pelajaran sehingga pembelajaran menjadi monoton dan kurang menyenangkan selain itu juga membuat peserta didik bersikap pasif dan acuh terhadap pembelajaran yang diberikan.

Dengan adanya permasalahan tersebut, maka peneliti dan guru sebagai pelaksana pembelajaran berkewajiban untuk berperan serta dalam upaya perbaikan proses pembelajaran. Salah satu cara yang dapat dilakukan adalah dengan menggunakan media film sebagai media pembelajaran Pendidikan Kewarganegaraan. Karena film Menurut Effendy (dalam Trianton 2013:2) merupakan media yang bersifat visual atau audio visual untuk menyampaikan pesan kepada sekelompok orang yang berkumpul disuatu tempat". Pada umumnya penggunaan film sebagai media pembelajaran di sekolahsekolah masih jarang digunakan. Sehingga pengaruh serta motivasi belajar peserta didik tidak berkembang dengan baik. Dengan demikian film sebagai media pembelajaran Pendidikan Kewarganegaraan akan memacu peserta didik untuk belajar lebih semangat, dapat mengembangkan pikiran dan pendapat peserta didik, mengembangkan imajinasi peserta didik, memperjelas hal-hal 
yang abstrak, memberikan gambaran yang lebih realistik dan diharapkan peserta didik akan mampu termotivasi untuk belajar.

Berdasarkan latar belakang masalah diatas, maka penulis merumuskan permasalahan penelitian ini sebagai berikut: "Bagaimana Pengaruh Penggunaan Media Film dalam Meningkatkan Motivasi Belajar Peserta didik Pada Mata Pelajaran Pendidikan Kewarganegaraan di SMA Negeri 6 Garut ?”. Dari rumusan masalah tersebut dibatasi dalam beberapa sub masalah sebagai berikut: 1. Bagaimana motivasi belajar peserta didik pada mata pelajaran Pendidikan Kewarganegaraan sebelum diterapkannya media film di kelas X SMA Negeri 6 Garut ? 2. Bagaimana motivasi belajar peserta didik pada mata pelajaran Pendidikan Kewarganegaraan sesudah diterapkannya media film di kelas X SMA Negeri 6 Garut ? 3. Bagaimana pengaruh penggunaan media film dalam meningkatan motivasi belajar peserta didik pada mata pelajaran Pendidikan Kewarganegaraan di kelas X SMA Negeri 6 Garut?

\section{METODE PENELITIAN}

Metode adalah suatu cara atau teknik yang dilakukan dalam proses penelitian. Sedangkan penelitian merupakan suatu upaya dalam bidang ilmu pengetahuan yang dijadikan untuk memperoleh fakta-fakta dalam prinsip-prinsip dengan sabar, hati-hati dan sistematis untuk menjawab kebenaran (Muhadjir, 2002:3).

Jadi metode penelitian adalah cara ilmiah untuk mendapatkan data dengan tujuan dan kegunaan penelitian.

Metode yang digunakan dalam penelitian ini adalah metode Eksperimen Menurut Sugiyono (2016:140) metode eksperimen dapat diartikan sebagai "metode penelitian yang digunakan untuk mencari pengaruh perlakuan tertentu terhadap yang lain dalam kondisi yang terkendali atau dalam penelitian ini peneliti dapat mengontrol semua variabel luar yang mempengaruhi jalannya eksperimen yang dipilih secara random".

Desain dalam penelitian ini merupakan rencana bagaimana penelitian dilaksanakan. Desain yang digunakan dalam penelitian ini adalah Pretest-Posttest Control Group Design dalam desain ini sebelum perlakuan diberikan terlebih dahulu masing-masing kelas diberi pretest (tes awal) kepada dua kelas untuk menentukan kelas eksperimen dan kelas kontrol kemudian nanti dilakukan perlakuan akhir posttest pada kelas eksperimen. Desain ini dilakukan sesuai tujuan yang hendak dicapai yaitu ingin mengetahui peningkatan motivasi belajar Pendidikan Kewarganegaraan pada peserta didik setelah menggunakan media pembelajaran film.

\section{A. Populasi dan Sampel Penelitian}

\section{a. Populasi Penelitian}

Yang menjadi populasi dalam penelitian ini adalah seluruh peserta didik kelas X SMA Negeri 6 Garut sebanyak 488 orang yang terdiri dari kelas (X BHS, X MIPA dan X IPS), dengan rincian sebagai berikut : Kelas X BHS 1, MIPA 1, MIPA 2, MIPA 3, MIPA 4, MIPA 5, MIPA 6, MIPA 7 , IPS 1, IPS 2, IPS 3 dan IPS 4.

\section{b. Sampel Penelitian}

Teknik sampling yang digunakan dalam penelitian ini adalah teknik sampling simple random sampling. Menurut Sugiyono (2016:120), pengertian simple random sampling yaitu dikatakan simpel (sederhana) karena pengambilan anggota sampel dari populasi dilakukan secara acak tanpa memperhatikan strata yang ada dalam populasi itu. Cara demikian dilakukan bila anggota populasi dianggap homogen. 
Dalam penelitian ini dibutuhkan dua sampel kelas, sedangkan populasi penelitian berjumlah 12 kelas maka peneliti menggunakan metode pengambilan Sampel Acak Sederhana (Simple Random Sampling), dengan cara pengambilannya menggunakan nomor undian untuk mendapatkan sampel kelas pertama. Setelah mendapatkan sampel pertama, maka peneliti mengundi kembali untuk mendapatkan sampel kelas yang kedua. Hasilnya peneliti menetapkan kelas X MIPA 7 yang berjumlah 40 orang peserta didik dan kelas X MIPA 1 yang berjumlah 40 orang peserta didik sebagai sampel penelitian. Dari penjelasan diatas maka yang menjadi sampel dalam penelitian ini adalah dua kelas yang terdiri dari 80 orang peserta didik, dan yang menjadi kelas eksperimen dalam penelitian ini adalah kelas X IPA 7 sedangkan sebagai kelas kontrol adalah kelas X IPA 1.

\section{B. Pengumpulan Data Penelitian}

Teknik pengumpulan data merupakan langkah yang paling utama dalam penelitian, karena tujuan utama dari penelitian adalah mendapatkan data. Tanpa mengetahui teknik pengumpulan data, maka peneliti tidak akan mendapatkan data yang memenuhi standar data yang ditetapkan. Untuk melengkapi metode yang penulis gunakan dalam mengumpulkan data-data tersebut maka diperlukan teknik penelitian. Adapun teknik penelitian yang digunakan adalah sebagai berikut:

\section{a. Tes}

Tes adalah serentetan pertanyaan atau latihan serta alat lain yang digunakan untuk mengukur keterampilan, pengetahuan intelegensi, kemampuan atau bakat yang dimiliki oleh individu atau kelompok.

\section{b. Wawancara Tidak Terstruktur (Interview)}

Wawancara tidak terstruktur adalah wawancara yang bebas dimana peneliti tidak menggunakan pedoman wawancara yang telah disusun secara sistematis dan lengkap untuk pengumpulan, pedoman wawancara yang digunakan hanya berupa garis besar pertanyaan yang akan ditanyakan. (Sugiyono, 2016:197)

\section{c. Observasi (Pengamatan)}

Observasi atau yang di sebut juga dengan pengamatan, meliputi kegiatan pemuatan perhatian terhadap suatu objek dengan menggunakan seluruh alat indera. Jadi, mengobservasi dapat dilakukan melalui penglihatan, penciuman, pendengaran, peraba dan pengecap. (Arikunto, 2013:199). Dalam penelitian ini peneliti akan melakukan kunjungan dan observasi langsung pada peserta didik kelas $\mathrm{X}$ di SMA Negeri 6 Garut.

\section{d. Angket (Kuisioner)}

Kuesioner merupakan teknik pengumpulan data yang dilakukan dengan cara memberi seperangkat pertanyaan atau pertanyaan tertulis kepada responden untuk dijawabnya. Kuesioner juga nerupakan teknik pengumpulan data yang efisien bila peneliti tahu dengan pasti variabel yang akan diukur dan tahu apa yang bisa diharapkan dari responden. (Sugiyono, 2016:199). Angket atau kuesioner dalam penelitian ini dilakukan pada peserta didik kelas X di SMA Negeri 6 Garut.

\section{Teknik Analisis Data Penelitian}

\section{a. Uji Normalitas Data Penelitian}

Uji normalitas data digunakan untuk mengetahui jenis statistik apa yang digunakan peneliti untuk pengolahan data selanjutnya dan Uji normalitas ini dilakukan untuk mengetahui apakah data kedua kelas sampel berada dipopulasi yang berdistribusi normal atau tidak.. Dalam uji ini peneliti menggunakan uji Lilliefors dengan taraf signifikan (a) sebesar 5\%. Kriteria Pengambilan keputusan: Jika Lmaks < Ltabel maka data berdistribusi normal. Dan Jika Lmaks > Ltabel maka data berdistribusi tidak normal.

\section{b. Uji Gain Ternormalisasi}

uji gain ternormalisasi ini digunakan untuk membandingkan hasil postest dan pretest. Gain yang dinormalisasi diperoleh dengan cara menghitung selisih antar skor postest dengan skor pretest dibagi oleh selisih antar skor maksimal dengan skor pretes. Peningkatan yang terjadi, sebelum dan 
sesudah pembelajaran dihitung dengan menggunakan rumus g-faktor (N-Gain) yang rumusnya (dalam sundayana, 2015:151).

$$
\mathrm{g}=\frac{\text { Skor postest }- \text { skor pretest }}{\text { Skor ideal-skor pretest }}
$$

\section{c. Uji Hipotesis}

Uji Hipotesis, yang berguna untuk menganalisis data sesuai dengan permasalahan penelitian. Adapun metode analisis yang digunakan untuk pengujian hipotesis adalah metode analisis regresi linear sederhana. Dalam hal ini yaitu perhitungan koefisien korelasi yang dilakukan dengan bantuan Microsoft Excel 2010. Perhitungan ini dilakukan untuk mencari hubungan fungsional antara variabel X dengan variabel Y. Menafsirkan besar kecilnya koefisien kolerasi dengan menggunakan interprestasi terhadap koefesien korelasi yang diperoleh menurut Arikunto, (2010: 319) sebagai berikut:

\begin{tabular}{|l|l|}
\hline \multicolumn{1}{|c|}{ Besarnya nilai } & \multicolumn{1}{|c|}{ Interpretasi } \\
\hline Antara $0,800-1,00$ & Tinggi \\
Antara $0,600-0,800$ & Cukup \\
Antara $0,400-0,600$ & Agak rendah \\
Antara $0,200-0,400$ & Rendah \\
Antara $0,000-0,200$ & $\begin{array}{l}\text { Sangat rendah } \\
\text { (tak berkolerasi) }\end{array}$ \\
\hline
\end{tabular}

\section{d. Uji Korelasi Pearson Product Moment}

Setelah data dari masing-masing variabel terkumpul, maka langkah selanjutnya adalah diadakan pengolahan data. Data yang bersifat statistik diolah dengan menggunakan analisis korerasi Produk Moment. Dalam menghitung adanya hubungan antara variabel X dengan variabel Y maka dilakukan teknik perhitungan statistik sebagai berikut ini. Tabel perhitungan yang terdiri dari enam kelompok yaitu:

1) Subjek penelitian,

2) Skor variabel $X$,

3) Skor variabel $Y$,

4) Hasil pengkuadratan seluruh skor variabel $X\left(X^{2}\right)$,

5) Hasil pengkuadratan seluruh skor variabel $Y\left(Y^{2}\right)$,

6) Hasil Perkalian antara skor variabel $\mathrm{X}$ dan Variabel $\mathrm{Y}=\mathrm{XY}$,

Menghitung korelasi/peranan Product Moment yaitu dengan menghubungkan Media Film (X) dalam Peningkatan motivasi belajar peserta didik (Y). Dengan mengunakan rumus sebagai berikut:

$$
r_{x y}=\frac{N\left(\sum X Y\right)-\left(\sum X\right)\left(\sum Y\right)}{\sqrt{\left(N \sum X^{2}-\left(\sum X\right)^{2}\right)\left(N \sum Y^{2}-\left(\sum Y\right)^{2}\right)}} \text { Keterangan : }
$$

rxy $=$ koefisien korelasi antara variabel $X$ dan variabel $Y$

$\mathrm{X}=$ nilai variabel $\mathrm{X}$

$\mathrm{Y}=$ nilai variabel $\mathrm{Y}$

$\mathrm{X}^{2}=$ nilai variable $\mathrm{X}$ yang dikuadratkan

$\mathrm{Y}^{2}=$ nilai variable $\mathrm{Y}$ yang dikuadratkan

$\mathrm{N}$ = jumlah sampel yang menjadi obyek peneliti.

Sundayana (2015:60) 
e. Uji Ttest

Uji T ini digunakan untuk mengetahui pengaruh dari variabel independen terhadap variabel dependen. Uji T ini dilakukan dengan membandingkan nilai thitung dengan nilai ttabel.

\section{f. Koefisien Determinasi}

Untuk menyatakan atau menentukan besar kecilnya sumbangan pengaruh variabel $\mathrm{X}$ terhadap variabel $\mathrm{Y}$, dapat dicari dengan rumus berikut ini : $\mathrm{D}=\left(\mathrm{r}_{\chi \gamma}\right)^{2} \mathrm{X} 100 \%$. (Sundayana,2015:202).

\section{HASIL PENELITIAN DAN PEMBAHASAN}

\section{A. Hasil Uji Normalitas Data Penelitian}

Hasil Uji Normalitas Tes Awal (Pretest) yang diberikan kepada sampel penelitian kelas Eksperimen dan Kelas Kontrol.

\begin{tabular}{|l|c|c|c|}
\hline \multicolumn{1}{|c|}{ Kelompok } & Lmax & Ltabel & Keterangan \\
\hline Kelas Eksperimen & 0,121 & 0,149 & Data Berdistribusi Normal \\
\hline Kelas Kontrol & 0,104 & 0,149 & Data Berdistribusi Normal \\
\hline
\end{tabular}

Dari hasil perhitungan uji normalitas diatas data hasil tes awal Pretest kelas Eksperimen diperoleh nilai $\mathrm{Lmax}=0,121$ lebih kecil dari Ltabel $=0,149$, maka dapat dikatakan bahwa sebaran data pada kelas eksperimen berdistribusi normal. Sedangkan data tes awal Pretest pada kelas kontrol diperoleh nilai $\operatorname{Lmax}=0,104$ lebih kecil atau kurang dari Ltabel $=0,149$ maka sebaran data tersebut berdistribusi normal.

Hasil Uji Normalitas Tes Akhir (Postest) yang diberikan kepada sampel penelitian kelas Eksperimen dan Kelas Kontrol.

\begin{tabular}{|l|c|c|c|}
\hline \multicolumn{1}{|c|}{ Kelompok } & Lmax & Ltabel & Keterangan \\
\hline Kelas Eksperimen & 0,141 & 0,149 & Data Berdistribusi Normal \\
\hline Kelas Kontrol & 0,143 & 0,149 & Data Berdistribusi Normal \\
\hline
\end{tabular}

Lmax $=0,141$ lebih kecil dari Ltabel $=0,149$, maka dapat disimpulkan bahwa sebaran data pada kelas eksperimen berdistribusi normal. Sedangkan data tes akhir Postest pada kelas kontrol diperoleh nilai Lmax $=0,104$ lebih kecil atau kurang dari Ltabel $=0,149$ maka sebaran data tersebut berdistribusi normal.

\section{B. Hasil Uji Korelasi}

Langkah selanjutnya adalah menentukan persamaan hubungan antar variabel dengan melakukan uji korelasi pearson product moment untuk mengetahui koefisien korelasi dalam hal ini peneliti menggunakan rumus pearson sebagai berikut :

$$
\begin{aligned}
& \quad r x y=\frac{n \sum x y-\left(\sum x\right)\left(\sum Y\right)}{\sqrt{\left[\left\{n \sum x^{2}-\left(\sum x\right)^{2}\right\}\right]\left[n \sum y^{2}-\left(\sum y\right)^{2}\right]}} \\
& \quad=\frac{(40 \times 1323,93)-(3123) \cdot(16,93)}{\sqrt{\left[\left\{40 \times 244,927-(3123)^{2}\right\}\right]\left[40 \times 12,71-(16,93)^{2}\right]}}=\frac{52957,20-52872,39}{\sqrt{[\{9797080-9753129\}][508,4-(286,6)]}}
\end{aligned}
$$




\section{Hasil Uji Hipotesis atau Uji t}

$$
\begin{aligned}
\text { thitung } & =\sqrt[r]{\frac{n-2}{1-r^{2}}} \quad=0,574 \sqrt[r]{\frac{40-2}{1-0,121}} \\
& =0,574 \sqrt[r]{\frac{38}{0,858}}=0,574 \sqrt[r]{44,28} \\
& =0,574 \sqrt[r]{6,654}=0,574 \times 6,654
\end{aligned}
$$

Hasil Uji t ini digunakan untuk untuk mengetahui keberartian korelasi apakah signifikan atau tidak.

\section{Hasil Uji Determinasi}

Untuk mengukur besarnya pengaruh terhadap penggunaan media film (Variabel X) dalam meningkatkan motivasi belajar peserta didik (Variabel Y), maka langkah selanjutnya adalah dengan menggunakan rumus koefisien determinasi, yaitu sebagai berikut :

$$
\begin{aligned}
D & =\left(r_{x y}\right)^{2} \times 100 \% \\
& =(0,574)^{2} \times 100 \% \\
& =0,329 \times 100 \% \\
& =32,9 \%
\end{aligned}
$$

Dari hasil penghitungan diatas maka Pengaruh Penggunaan Media Film dalam Meningkatkan Motivasi Belajar peserta didik pada mata pelajaran pendidikan kewarganegaraan di SMA Negeri 6 Garut (Studi Eksperimen terhadap kelas x SMA Negeri 6 Garut), adalah sebesar 32,9\% dan sisanya sebesar $67,1 \%$ dipengaruhi oleh variabel lain.

Dari hasil penghitungan dengan menggunakan bantuan aplikasi SPSS for windows 16.0 dan Microsoft Excel 2010 menggambarkan bahwa motivasi belajar peserta didik pada mata pelajaran Pendidikan Kewarganegaraan tergolong dalam kategori Tinggi, hal ini dibuktikan dengan perolehan uji koefisien korelasi yaitu sebesar 32,9\% dan sisanya sebesar 67,1\% dipengaruhi oleh variabel lain. Dengan demikian terdapat korelasi yang signifikan antar variabel yaitu motivasi belajar peserta didik pada mata pelajaran pendidikan kewarganegaraan meningkat dengan menggunakan media film.

Media film dalam pembelajaran PKn dapat meningkatkan motivasi belajar peserta didik serta pesan moral yang terdapat dalam film dapat dijadikan sebagai contoh untuk di implementasikan dalam kehidupan sehari-hari peserta didik. Menurut Kustandi dan Sutjipto (2016:64). Media pembelajaran Film merupakan gambar-gambar dalam frame. Dalam media ini, setiap frame diproyeksikan melalui lensa proyektor secara mekanis sehingga pada layar terlihat gambar itu hidup, film bergerak dengan cepat dan bergantian sehingga memberikan visualisasi yang kontinu dan dapat menggambarkan suatu objek yang bergerak bersama-sama dengan suara alamiah atau suara yang sesuai, film dapat menyajikan informasi, memaparkan proses, menjelaskan konsep-konsep yang rumit, mengajarkan keterampilan, menyingkat atau memperpanjang waktu, dan mempengaruhi sikap.

Begitu pula dengan motivasi belajar peserta didik, hasil penelitian menunjukkan bahwa motivasi belajar peserta didik pada mata pelajaran pendidikan kewarganegaraan di kelas X SMA Negeri 6 Garut tergolong dalam kategori baik yakni memperoleh nilai 32,9\%. Dengan demikian peserta didik senang, tertarik dan tingginya hasrat belajar pelajaran pendidikan kewarganegaraan menggunakan 
media film. Hal ini sesuai dengan pendapat Hamzah (2017:23) Motivasi belajar dapat timbul karena faktor intrinsik, berupa hasrat dan keinginan berhasil dan dorongan kebutuhan belajar, harapan akan cita-cita. Sedangkan faktor ekstrinsiknya adalah adanya penghargaan, lingkungan belajar yang kondusif, dan kegiatan belajar yang menarik. Berdasarkan pendapat diatas bahwa motivasi belajar peserta didik itu dipengaruhi oleh faktor intrinsik dan ekstrinsik kedua faktor tersebut disebabkan oleh rangsangan dari dal dan dari luar yang mempengaruhi hasil belajar peserta didik, sehingga seseorang berkeinginan untuk melakukan aktivitas pembelajaran atau belajar yang lebih giat dan semangat.

Dalam kegiatan belajar, motivasi dapat dikatakan sebagai keseluruhan daya penggerak di dalam diri siswa yang menimbulkan kegiatan belajar, yang menjamin kelangsungan dari kegiatan belajar dan yang memberikan arah pada kegiatan belajar, sehingga tujuan yang dikehendaki oleh subjek belajar itu dapat tercapai salah satunya adalah tujuan dari mata pelajaran Pendidikan kewarganegaraan yaitu diharapkan dapat menumbuhkan dan meningkatkan partisipasi warga negara dalam kehidupan politik dan masyarakat baik pada tingkat lokal maupun nasional, maka untuk menumbuhkan dan meningkatkan partisipasi semacam itu diperlukan pengembangan sejumlah kompetensi. Dan mata pelajaran yang memfokuskan pada pembentukan karakter warga negara dalam pembelajaran di sekolah, pembelajaran Pendidikan Kewarganegaraan dapat dikaitkan dengan kehidupan sehari-hari. Dengan mengaitkan pembelajaran Pendidikan Kewarganegaraan dengan kehidupan nyata dapat membentuk perilaku sesuai dengan nilai-nilai yang diharapkan, selain itu Pendidikan Kewarganegaraan dapat diartikan juga sebagai mata pelajaran yang memfokuskan pembentukan warga negara yang memahami dan mampu melaksanakan hak-hak dan kewajibannya untuk menjadi warga negara Indonesia yang cerdas, terampil, dan berkarakter yang diamanatkan oleh Pancasila dan UUD 1945. Sehingga apabila motivasi belajar peserta didik sudah baik maka tujuan dari mata pelajaran Pendidikan kewarganegaraan pun akan mudah direalisasikan.

Hasil penelitian membuktikan bahwa penggunaan media film pada mata pelajaran Pendidikan Kewarganegaraan memiliki pengaruh yang signifikan terhadap peningkatan motivasi belajar peserta didik. Dengan adanya pengaruh yang positif tersebut, maka dapat diartikan jika peserta didik mengalami perubahan pada arah yang lebih baik yaitu ketertarikan, kesenangan dan hasrat belajar pada mata pelajaran Pendidikan Kewarganegaraan menjadi semakin meningkat dan sangat antusias bilamana didalam pembelajaran melibatkan film sebagai media pembelajarannya.

Dari hasil penelitian, dengan mengolah dan analisis data melalui penyebaran angket menunjukkan bahwa didapatkan koefisien korelasi penggunaan media Film pada mata pelajaran Pendidikan Kewarganegaraan sebesar 0,826 sedangkan koefisien korelasi motivasi belajar peserta didik pada mata pelajaran Pendidikan Kewarganegaraan yaitu sebesar 0,751. Ini berarti bahwa Penggunaan Media Film dalam Meningkatkan Motivasi Belajar Peserta Didik Pada Mata Pelajaran Pendidikan Kewarganegaraan berada pada kisaran 0,800 - 1,00 dengan interpretasi "Tinggi”.

Berkaitan dengan hal tersebut maka media pembelajaran film ini dimaksudkan sebagai alternatif untuk mengajarkan suatu materi pembelajaran sebagai alat bantu yang dapat dilihat dan didengar yang dipakai dalam proses pembelajaran dengan maksud untuk membuat cara berkomunikasi lebih efektif dan efisien dan bertujuan untuk meningkatkan fokus perhatian peserta didik terhadap materi pelajaran, menggugah perasaan, emosi, dan tingkat penerimaan atau penolakan peserta didik terhadap sesuatu, mampu menceritakan pengalamannya selama melakukan kegiatan dari proses melihat dan mendengar tersebut kepada temannya, dapat meningkatkan dan mengembangkan imajinasi peserta didik, serta sebagai seni dalam upaya mendorong peserta didik untuk terdorong melakukan kegiatan belajar sehingga motivasi belajar peserta didik menjadi meningkat dan tertarik pada mata pelajaran PKn serta tujuan pembelajaranpun dapat tercapai yaitu khususnya mata pelajaran Pendidikan Kewarganegaraan. 
Karena mata pelajaran Pendidikan Kewarganegaraan bertujuan supaya peserta didik Berpikir secara kritis, rasional dan kreatif dalam menanggapi isu kewarganegaraan. Berpartisipasi secara aktif dan bertanggung jawab dan bertindak secara cerdas dalam kegiatan bermasyarakat, berbangsa, bernegara, serta anti korupsi. Berkembang secara positif dan demokratis untuk membentuk diri berdasarkan karakter-karakter masyarakat indonesia agar dapat hidup bersama dengan bangsa-bangsa lain. Dan Berinteraksi dengan bangsa-bangsa lain dalam peraturan dunia secara langsung atau tidak langsung dengan memanfaatkan teknologi informasi dan komunikasi.

Untuk mencapai tujuan tersebut maka seyogyanya pembelajaran Pendidikan Kewarganegaraan tidak hanya didominasi dengan ceramah yang dilakukan guru namun melibatkan peserta didik untuk berpartisispasi secara langsung dalam pembelajaran dan penggunaan media yang tepat juga sangat berpengaruh terhadap motivasi belajar peserta didik. karena kata kunci dalam pembelajaran Pendidikan Kewarganegaraan ialah partisipasi. Untuk itu guru dapat membuat rancangan kegiatan yang memunculkan partisipasi peserta didik dalam belajar sehingga dapat mencapai tujuan Pendidikan Kewarganegaraan yang telah ditentukan dan salah satunya adalah dengan penggunaan media Film dalam upaya meningkatkan motivasi belajar peserta didik pada mata pelajaran Pendidikan Kewarganegaraan.

\section{SIMPULAN}

Saat pembelajaran kondisi atau motivasi belajar peserta didik sebelum diberi perlakuan yaitu menggunakan media film sebagai media pembelajaran belum bisa dikatan merata. Karena masih ada peserta didik acuh, cuek pasif, bosan, kurang tertarik, tidak adanya antusias dan hasrat atau semangat belajar ketika guru sedang memberikan materi pembelajaran. Disini peran guru sangatlah penting agar bagaimana peserta didik mampu senang, adanya hasratnya belajar yang tinggi dan mampu tertarik memiliki keinginan dan kemampuan untuk belajar sehingga mampu termotivasi untuk sungguh-sungguh dalam belajar sehingga tujuan pembelajaran dapat tercapai dengan baik.

Pada saat proses pembelajaran di kelas X SMA Negeri 6 Garut ketika guru memakai media film barulah terlihat perubahan yang signifikan peserta didik menjadi senang, munculnya hasrat belajar yang tinggi dan tertarik pada mata pelajaran yang disampaikan guru. Sebab pembelajaran dengan media film ini fokus pembelajaran bukan hanya pada aspek kognitif saja, tetapi juga dapat meliputi ranah afektif dan psikomotorik peserta didik. Jadi seluruh aspek tersebut dapat terlibat secara nyata yang melibatkan unsur emosional peserta didik dan mendapatkan pengalaman belajar yang lebih konkret sehingga motivasi belajar peserta didik menjadi tinggi atau meningkat. Selain itu hasrat belajar peserta didik pun meningkat, yang membuat peserta didik menjadi senang dan tertarik pada pembelajaran. Sehingga pengaruh penggunaan media dalam meningkatkan motivasi belajar peserta didik cukup signifikan.

Pengaruh penggunaan media film dalam meningkatkan motivasi belajar peserta didik pada mata pelajaran pendidikan kewarganegaraan (PKn) di SMA Negeri 6 Garut hasilnya sangat signifikan berpengaruh, motivasi belajar peserta didik pada mata pelajaran PKn dengan menggunakan media film meningkat setelah pembelajaran menggunakan media film yang diberikan kepada kelas eksperimen, suasana belajarpun menjadi lebih aktif, antusias dan partisipasi dari peserta didikpun sangat tinggi selain itu juga peserta didik mudah menerima materi pembelajaran dan mendapatkan pengalaman belajar yang lebih baik dibandingkan dengan pembelajaran tanpa menggunakan media apapun atau pembelajaran secara konvensional yang membuat peserta didik menjadi kurang aktif, ketertarikan peserta didik pada mata pelajaran PKn pun rendah. Karena pembelajaran dengan media film dalam proses pembelajaran materi pelajaran dikemas dalam bentuk audio visual, serta memberikan contoh atau kisah nyata yang ditayangkan dalam bentuk film baik itu film dalam jenis berita, dokumenter, film cerita atau drama dan sebagainya, selain itu juga mudah diingat oleh peserta 
didik karena melibatkan unsur pandang dan dengar yang membuat peserta didik menjadi fokus pada pelajaran yang disampaikan guru.

\section{DAFTAR PUSTAKA}

[1] A.A. Suwasono, (2014). Pengantar Film. Yogyakarta: Badan Penerbit ISI Yogyakarta.

[2] Aqib. Zaenal. (2009). Penelitian Tindakan Kelas, Bandung: Ayrama Widya.

[3] Arikunto, Suharsimi. (2013), Prosedur Penelitian Suatu Pendekatan Praktik. Jakarta : Rineka, Cipta.

[4] Arsyad, Azhar. (2013). Media Pembelajaran. Jakarta : Rajawali Pers.

[5] Asnawir dan Basyirudin Usman (2002). Media Pembelajaran. Jakarta: Ciputat Press.

[6] Budimansyah dan Suryadi.(2008). Kompetensi Pendidikan Kewarganegaraan. Jakarta: Erlangga Group.

[7] Cecep Kustandi dan Bambang Sutjipto.(2016), Media Pembelajaran. Bogor: Ghalia Indonesia.

[8] Depdiknas. (2003). UU No. 20 Tahun 2003 Tentang Sisdiknas. Jakarta: Depdiknas.

[9] Dimyati dan Mudjiono. (2009). Belajar dan Pembelajaran. Jakarta: Rineka Cipta.

[10] Hamalik, Oemar. (2009). Psikologi Belajar dan Mengajar. Bandung: Sinar Baru Algensindo

[11] Hamzah, Uno. (2017). Teori Motivasi dan Pengukurannya, Jakarta: Bumi Aksara.

[12] Heru Effendy. (2009). Mari Membuat Film. Jakarta: Erlangga

[13] Kompri. (2016). Motivasi Pembelajaran Perspektif Guru dan Siswa. Bandung : PT Remaja Rosdakarya

[14] Kustandi dan Sutjipto. (2016:57-68). Media Pembelajaran Edukatif. Bandung: Sinar Baru Algensindo

[15] Marselli Sumarno. (1996). Dasar-Dasar Apresiasi Film. Jakarta: Gramedia Widiasarana Indonesia.

[16] Sadiman Arif Dkk. (2010). Media Pendidikan. Jakarta: Raja Grafindo Persada.

[17] Sardiman. (2014). Interaksi dan motivasi Belajar Mengajar, Jakarta: Raja Grafindo Persada

[18] Sundayana. (2015). Statistika Penelitian Pendidikan, Bandung: Alfabeta.

[19] Tetep. (2015). Penanaman Nilai-Nilai Karakter Sosial Siswa Dalam Pendidikan Kewarganegaraan dan IPS Dalam Konteks Perpspektif Global. E-Jurnal PETIK Vol 2 No. 2 tahun 2016. https://journal.institutpendidikan.ac.id/index.php/petik/issue/view/6. DOI: http://dx.doi.org/10.31980/ipetik.v2i2

[20] Winarno. (2008),Paradigma Pendidikan Kewarganegaraan. Jakarta: Bumi Aksara. 